ISSN 1392-3196 / e-ISSN 2335-8947

Zemdirbyste-Agriculture, vol. 101, No. 4 (2014), p. 395-402

DOI $10.13080 / \mathrm{z}-\mathrm{a} .2014 .101 .050$

\title{
The influence of soil preparation on the development of ground vegetation in forest plantations on arable farmland and forest clear-cut areas
}

\author{
Vytautas SUCHOCKAS ${ }^{1,2}$, Antanas MALINAUSKAS ${ }^{1}$, Gintautas URBAITIS ${ }^{1}$, Alfas PLIŪRA ${ }^{1,2}$ \\ ${ }^{1}$ Institute of Forestry, Lithuanian Research Centre for Agriculture and Forestry \\ Liepų 1, Girionys, Kaunas distr., Lithuania \\ E-mail: suchockas@centras.lt \\ ${ }^{2}$ Aleksandras Stulginskis University \\ Studentų 11, Akademija, Kaunas distr., Lithuania
}

\begin{abstract}
The influence of soil preparation on the development of ground vegetation during the establishment of forest plantations was studied. It was found that in the first-year plantations on former farmland the least biomass of ground vegetation develops on furrows. Complete soil tillage to the depth of 22-27 cm, ploughed in berms or elimination of weeds with Roundup Bio may reduce the biomass of ground vegetation by up to two times. Soil ploughing in berms or piles always reduced the mass of weeds.

In the second year of plantations' growth, differences in the biomass of weeds among different soil preparation treatments decreased. On fresh clear-cut areas of fertile mineral soils any mechanical method of soil preparation reduced the biomass of ground vegetation. With increasing soil preparation depth (down to $40 \mathrm{~cm}$ ) and the width of the strip (up to $100 \mathrm{~cm}$ ), the biomass of ground vegetation decreased.

The least (4-9 times less compared with unprepared soil) ground vegetation biomass was observed when the soil had been prepared in furrows, berms or piles. Soil preparation method affected also the height of ground vegetation. It depended on soil fertility and moisture content, weed species, spring and summer weather conditions.

The shading class of seedlings and the volume of plantation tending depended on soil preparation method too. Seedlings planted on wide $(100 \mathrm{~cm}$ ) furrows and on $30 \mathrm{~cm}$ high piles were the least shaded, while those growing on unprepared, completely ploughed soil or on inverted humus mounds experienced the greatest suppression.
\end{abstract}

Key words: berm, development of ground vegetation, forest plantations, furrow, soil preparation.

\section{Introduction}

The success of forest regeneration and plantation establishment is considerably influenced by the competing ground vegetation (Thompson, Pitt, 2003). The growth and development of competing vegetation depends on the characteristics (fertility and moisture content) of the planting area (Pawers, Reynolds, 1999), species composition of the competing vegetation (Miller et al., 2003), silvicultural measures (Gemmel et al., 1996), as well as on the size of planted species and seedlings (Reynolds et al., 2002; Rosse, Ketchum, 2003).

Having felled stand of medium or high stocking level, the number of ground vegetation species and their projection covering substantially decrease. In the secondthird year after felling, projection covering of the ground vegetation rapidly augments, and its maximum is reached, depending on forest type, in the fourth-seventh year after felling (Юряленис, 1975). Heath-rush (Juncus sp.) (50\%) starts prevailing in the ground vegetation in Myrtillooxalidosum forest types, followed by Deschampsia flexuosa (L.) Trin. In Oxalidosum forest types, Pteridium aquilinum (L.) Kuhn) and Calamagrostis arundinacea (L.) Roth) become widespread, while in Hepatico- oxalidosum - Rubus idaeus L. (80\% of the area). A significantly smaller area is covered by $C$. arundinacea. In the clear-cuts of Oxalido-nemorosum forest types Deschampsia cespitosa (L.) P.Beauv., Rubus idaeus and Juncus occupy almost equal areas. On the forest clearcuts areas of Aegopodiosum types prevails Aegopodium podagraria L., followed by Cirsium, Ranunculus, Geum, which, in the case when $A$. podagraria fails to become widespread, may occupy a prevailing position, while in the forest clear-cuts areas of Mixtoherbosum forest types Calamagrostis canescens (Weber) Roth becomes the most widespread, smaller areas are occupied by D. cespitosa, and Juncus sp. (Юряленис, 1975).

Establishing plantations on former farmland, the competition from ground vegetation may have detrimental effect on the cultivated plants (Hytönen, Jylhä, 2005). The afforestation of former farmlands is by far more difficult than that of cutovers. Farmlands and abandoned lands contain over 50000 viable seeds of mostly pioneer species per $1 \mathrm{~m}^{2}$ (Kiirikki, 1993). The seeds may remain viable for a very long period of more than 20 years (Kiirikki, 1993). Annual weeds are 
followed by perennial ones. Weeds prevail for a long time since afforestation and this cover fails to become normal forest even after 16-17 years (Rossi et al., 1993). In 35-50-year-old plantations or naturally regenerated forests on former farmland, ground vegetation typical of forest already prevails, although quite frequently vegetation typical of farmlands is observed (Malinauskas, Ubaitis, 2002; 2010).

One of the most important problems encountered when afforesting former farmlands is control of development of ground vegetation, the growth and development of which is much faster than on forest soils (Hytönen, Jylhä, 2005). The main factor preconditioning faster growth of the ground vegetation on former farmland is a higher amount of nutrients (Hytönen, Ekola, 1993; Hytönen, Wall, 1997).

Competingvegetationisdestroyed(mechanically or chemically), its growth and development is restricted, at the same time affecting the cultivated plants (hay-making, trampling, mulching, planting of grasses). The spreading and growth of the competing vegetation may be significantly influenced by the preparation of the planting site (Smirh et al., 1997).

The aim of this work was to ascertain the influence of different soil preparation methods on the distribution of the competing vegetation in the cutovers on normally humid and temporarily overmoistured soils, as well as on former farmlands of different fertility and humidity.

\section{Materials and methods}

The research trial was set up at the Institute of Forestry, Lithuanian Research Centre for Agriculture and Forestry. The studies on the influence of soil preparation on the distribution of competing vegetation were conducted in the clear-cuts of deciduous with spruce and broadleaved stands of Hepatico-oxalidosum, Oxalidonemorosum and Aegopodiosum forest types (according to Karazija, 1988) in Panevèžys, Tauragè and Telšiai forest enterprises (Table 1). The soils in the testing plots were classified as Podsol (JD), Luvisol (ID) and Albeluvisol (JI) (according to Buivydaite et al., 2001).

Table 1. The description of the testing areas

\begin{tabular}{|c|c|c|c|}
\hline $\begin{array}{l}\text { Location of } \\
\text { testing plots }\end{array}$ & Soil group & Soil preparation method & $\begin{array}{l}\text { Number of } \\
\text { replications }\end{array}$ \\
\hline $\begin{array}{l}\text { Anykščiai } \\
\text { forest } \\
\text { enterprise }\end{array}$ & $\begin{array}{l}\text { Relatively } \\
\text { infertile dry soil } \\
\text { sandy Podsol }\end{array}$ & $\begin{array}{l}\text { 1. No site preparation. } \\
\text { 2. Complete site ploughing (depth } 22-27 \mathrm{~cm}) \text {. } \\
\text { 3. Furrow (depth } 8-10 \mathrm{~cm} \text {, width } 50 \mathrm{~cm}) \text {. }\end{array}$ & $\begin{array}{l}3 \\
3 \\
3\end{array}$ \\
\hline $\begin{array}{l}\text { Panevėžys } \\
\text { forest } \\
\text { enterprise }\end{array}$ & $\begin{array}{l}\text { Relatively fertile } \\
\text { dry soil sandy } \\
\text { loamy Luvisol }\end{array}$ & $\begin{array}{l}\text { 1. Furrow (depth } 8-10 \mathrm{~cm} \text {, width } 50 \mathrm{~cm}) \text {. } \\
\text { 2. Furrow (depth } 8-10 \mathrm{~cm} \text {, width } 70 \mathrm{~cm}) \text {. } \\
\text { 3. Complete site ploughing and cultivation. } \\
\text { 4. Spraying of Roundup Bio }\left(41 \mathrm{ha}^{-1}\right) \text { without site ploughing. }\end{array}$ & $\begin{array}{l}4 \\
4 \\
4 \\
4\end{array}$ \\
\hline $\begin{array}{l}\text { Anykščiai } \\
\text { forest } \\
\text { enterprise }\end{array}$ & $\begin{array}{l}\text { Relatively fertile } \\
\text { dry soil sandy } \\
\text { loamy Luvisol }\end{array}$ & $\begin{array}{l}\text { 1. No site preparation. } \\
\text { 2. Furrow (depth } 15 \mathrm{~cm} \text {, width } 70 \mathrm{~cm} \text { ). } \\
\text { 3. Complete site ploughing (depth } 22-27 \mathrm{~cm} \text { ). } \\
\text { 4. Furrow (depth } 8-10 \mathrm{~cm} \text {, width } 50 \mathrm{~cm} \text { ). }\end{array}$ & $\begin{array}{l}3 \\
3 \\
3 \\
3\end{array}$ \\
\hline $\begin{array}{l}\text { Telšiai forest } \\
\text { enterprise }\end{array}$ & $\begin{array}{l}\text { Relatively fertile } \\
\text { dry soil sandy } \\
\text { loamy Luvisol }\end{array}$ & $\begin{array}{l}\text { 1. Furrow (depth } 15 \mathrm{~cm} \text {, width } 100 \mathrm{~cm}) \text {. } \\
\text { 2. Complete site ploughing (depth } 22-27 \mathrm{~cm}) \text {. } \\
\left.\text { 3. Spraying of Roundup Bio }\left(41 \mathrm{ha}^{-1}\right)+\text { complete site ploughing (depth } 22-27 \mathrm{~cm}\right) \text {. } \\
\text { 4. Inverted humus mound (width } 50 \mathrm{~cm} \text {, height } 20 \mathrm{~cm}) . \\
\text { 5. Spraying of Roundup Bio }\left(41 \mathrm{ha}^{-1}\right)+\text { inverted humus mound (width } 50 \mathrm{~cm} \text {, } \\
\text { height } 20 \mathrm{~cm}) \text {. }\end{array}$ & $\begin{array}{l}3 \\
3 \\
3 \\
3 \\
3\end{array}$ \\
\hline $\begin{array}{l}\text { Tauragè } \\
\text { forest } \\
\text { enterprise }\end{array}$ & $\begin{array}{l}\text { Fertile dry soil } \\
\text { light loamy } \\
\text { Albeluvisol }\end{array}$ & $\begin{array}{l}\text { 1. No site preparation. } \\
\text { 2. Furrow (depth } 8-10 \mathrm{~cm} \text {, width } 70 \mathrm{~cm}) \\
\text { 3. Complete site ploughing }(\text { depth } 22-27 \mathrm{~cm}) \\
\text { 4. Tilt ploughing (height } 25 \mathrm{~cm}) \\
\text { 5. Soil piles }(60 \times 80 \times 30 \mathrm{~cm})\end{array}$ & $\begin{array}{l}4 \\
4 \\
4 \\
4 \\
4\end{array}$ \\
\hline $\begin{array}{l}\text { Tauragè } \\
\text { forest } \\
\text { enterprise }\end{array}$ & $\begin{array}{l}\text { Fertile fresh soil } \\
\text { loamy Luvisol }\end{array}$ & $\begin{array}{l}\text { 1. Complete site ploughing }(\text { depth } 22-27 \mathrm{~cm}) \\
\text { 2. Tilt ploughing (height } 25 \mathrm{~cm}) \\
\text { 3. Soil piles }(60 \times 80 \times 30 \mathrm{~cm})\end{array}$ & $\begin{array}{l}4 \\
4 \\
4\end{array}$ \\
\hline $\begin{array}{l}\text { Telšiai forest } \\
\text { enterprise }\end{array}$ & $\begin{array}{l}\text { Fertile dry soil } \\
\text { and fertile fresh } \\
\text { soil loamy } \\
\text { Luvisol, } \\
\text { loamy Luvisol } \\
\text { with the features } \\
\text { of Albeluvisol }\end{array}$ & $\begin{array}{l}\text { 1. Furrow (depth } 15 \mathrm{~cm} \text {, width } 100 \mathrm{~cm}) \text {. } \\
\left.\text { 2. Spraying of Roundup Bio }\left(41 \mathrm{ha}^{-1}\right)+\text { furrow (depth } 15 \mathrm{~cm} \text {, width } 100 \mathrm{~cm}\right) \text {. } \\
\text { 3. Complete site ploughing (depth } 22-27 \mathrm{~cm}) \text {. } \\
\text { 4. Spraying of Roundup Bio }\left(41 \mathrm{ha}^{-1}\right)+\text { complete site ploughing (depth } 22-27 \mathrm{~cm} \text { ). } \\
\text { 5. Inverted humus mound (width } 50 \mathrm{~cm} \text {, height } 20 \mathrm{~m}) . \\
\text { 6. Spraying of Roundup Bio }\left(41 \mathrm{ha}^{-1}\right)+\text { inverted humus mound (width } 50 \mathrm{~cm} \text {, } \\
\text { height } 20 \mathrm{~cm}) \text {. }\end{array}$ & $\begin{array}{l}3 \\
3 \\
3 \\
3 \\
3\end{array}$ \\
\hline
\end{tabular}

The soil was prepared in 2006-2008 in the following ways: ploughed tilts (berms) of different thickness $(10,20,30,40 \mathrm{~cm})$ and width $(40,60,80,100$ $\mathrm{cm}) ; 20-30 \mathrm{~cm}$ thick, $50-60 \mathrm{~cm}$ wide mounds of inverted humus; in $80 \mathrm{~cm}$ wide strips, mixing the litter with the mineral horizons at $20 \mathrm{~cm}$ depth, as well as in $20-40 \mathrm{~cm}$ high piles of $60 \mathrm{~cm}$ in width and $80 \mathrm{~cm}$ in length. The soil was prepared in three replications. The size of testing plots varied from 200 to $300 \mathrm{~m}^{2}$. One hundred trees were planted in each replication. 
Studies on the influence of different soil preparation methods on the abundance of weed vegetation in the first and second year plantations on former arable farmlands were carried out in Anykščiai, Panevėžys, Tauragè and Telšiai forest enterprises. The number of replications of different soil preparation methods in one site was 3-4, except soil preparation on relatively fertile dry soil in Telšiai forest enterprise in $50 \mathrm{~cm}$ wide and $20 \mathrm{~cm}$ high inverted humus mound (three replications). The soil was prepared in August-September. In the replications involving chemical soil preparation, the chemical treatment was carried out two weeks before the mechanical soil preparation. The dose of 41 ha $^{-1}$ of glyphosate standard preparation Roundup Bio $360 \mathrm{ml}$ of active ingredient per litre was used.

The plantation was established in the spring of the following year. The biomass of above ground vegetation was ascertained in the second half of August - the first half of September, next year following soil preparation, cutting it at the ground level in $40 \times 50 \mathrm{~cm}$ sized sampling plots (at 10 sampling plots for each replication). Later the biomass was dried at $105^{\circ} \mathrm{C}$ temperature until oven dry weight, and weighed.

Biomass of the competing vegetation, species composition, the prevailing species and their mean height have been ascertained. For this reason, in each sampling plot 50 highest plants were selected and measured for height with an accuracy of $1 \mathrm{~cm}$. Shading class of the ground vegetation on each seedling was assessed as follows: no shading (0), one quarter (1), half (2), or three quarters of the seedling in shade (3) and fully shaded (4) (Hytönen, Jylhä, 2005).

Tending of the plantation was carried out in the first two weeks of July by destroying weeds with a hoe at a radius of $25 \mathrm{~cm}$ around seedlings.

The data statistics were presented as mean from the replicates and were reported as mean \pm standard error of the mean using analysis of variance procedures. Statistical significance (at $P \leq 0.05$ and $P \leq 0.01$ ) of differences between means of treatments and control was estimated using $t$-test (the PDIFF option under the mixed procedure of the software $S A S^{\circledR}$ Analytical Products 12.1) (SAS Institute Inc., USA, 2012).

\section{Results}

One of the primary objectives of soil preparation for forest plantations is the reduction or elimination of the competition from the ground vegetation. Some soil preparation methods may significantly reduce the further tending of plantations. In the clear-cuts of normal humidity, soil may be prepared at surface level, lower or higher than the general soil surface, while in the cutovers of temporarily overmoistured soils planting places should be higher or at the same level as the ground level. In Hepatico-oxalidosum forest type cutover of broadleaved (aspen and birch) stand with Norway spruce, the dry biomass of ground vegetation in the first year of plantation growth comprised on an average $395 \mathrm{~g} \mathrm{~m}^{-2}$ (Table 2). The dry biomass of weeds in the soil prepared in ploughed tilts, depending on the thickness and width of the berm, comprised $28-56 \%$ of the biomass found in unprepared soil, on loosened strips respectively $30 \%$, on strips ploughed at ground surface $-4-21 \%$, while on 10 $\mathrm{cm}$ deep furrows $-12 \%$. With increasing ploughing depth from 10 to $30 \mathrm{~cm}$, the dry biomass of weeds decreased in average twice, while with increasing tilt width from 40 to $100 \mathrm{~cm}-1.6$ times.

Soil preparation reduces not only the biomass of weeds but also the height. Mean height of weeds in Hepatico-oxalidosum forest type on unprepared soil was $90 \mathrm{~cm}$, while in soil prepared by different methods $-40-70$ $\mathrm{cm}$. In the clear-cuts of temporarily overmoistured soils (Oxalido-nemorosum and Aegopodiosum forest type), the biomass of weeds, depending on soil preparation method, varied similarly to Hepatico-oxalidosum forest type, but their mass in the first year of plantation growth was lower. It depended on the species composition of weeds. If on Hepatico-oxalidosum forest type the most widespread are Rubus idaeus L., Calamagrostis arundinacea (L.) Roth), Urtica dioica L., then on Oxalido-nemorosum site - Deschampsia cespitosa (L.) P.Beauv., Calamagrostis canescens (Weber) Roth, Juncus, while R. idaeus and $C$. arundinacea is observed less frequently. On the fresh cutovers of Aegopodiosum stands broadleaved weeds prevailed: Aegopodium podagraria L., Impatiens nolitangere L., Ranunculus repens L., Galium palustre L. In the first year of plantation growth, in prepared soil the weeds were only about $20 \mathrm{~cm}$ in height and were not able to shade the cultivated plants. In the second and the third year, the biomass and height of weeds, especially in prepared soil, increased, the species composition of weeds underwent changes, the amount of grain grasses increased, but even in plantations of the third year the biomass of weeds on mounds was twice as low as that in unprepared soil. In the third year of the growth of plantation, weed-free piles and berms of soil occurred sometimes

The biomass of weed vegetation on former farmlands of similar fertility is higher than in forest soils, while soil preparation may have a rather distinct, but most often significantly less influence (Fig.). In the plantations of the first year, independent of soil fertility and moisture content, the least biomass of weeds was on furrows, while considerably higher on the soil prepared in other ways. On $15 \mathrm{~cm}$ deep furrows the biomass of weeds was less than on $8-10 \mathrm{~cm}$ deep furrows.

The following soil preparation methods complete soil ploughing (to 22-27 cm depth), its preparation in tilts and killing of weeds by Roundup Bio - may decrease the biomass of weeds by up to two times. Other soil preparation methods reduce the mass of weeds too. Weed-killing by Roundup Bio prior to mechanical soil preparation reduced the mass of weeds in average by $1.2-2.6$ times. Essentially $(P \leq 0.01)$ differs only the thickness of piles and berms formed inverting the soil to $180^{\circ}$. Lower (1.4-1.9 times) biomass of weeds in the soil prepared in piles, as compared to tilts, was due to the fact that some piles contained inverted outside illuvial horizon.

In the second year of the growth of plantation, differences in the biomass among different soil preparation methods decreased; however, the tendencies remained similar. In the unprepared soil of former farmland Gramineae weeds, such as Elytrigia repens (L.) Nevski, Dactylis glomerata L., Agrostis capillaris L. and $A$. canina prevailed. On relatively infertile dry soils Elytrigia repens prevailed, meanwhile on fertile soils Dactylis glomerata and Agrostis sp., Poa annua L. prevailed. Along with Gramineae, on relatively infertile dry soils most frequently occured Solidago virgaurea L., 
Table 2. Total weight and mean height of highest weeds in fresh forest clear-cut areas depending on soil preparation methods in the first year of forest plantations

\begin{tabular}{|c|c|c|c|c|}
\hline \multicolumn{3}{|c|}{ Soil preparation method } & $\begin{array}{l}\text { Oven dried above ground biomass of } \\
\text { weeds } \mathrm{g} \mathrm{m}^{-2} \\
\text { (mean } \pm \text { standard error of the mean) }\end{array}$ & $\begin{array}{c}\text { Mean height of the highest weeds } \\
\mathrm{cm} \\
\text { (mean } \pm \text { standard error of the mean) }\end{array}$ \\
\hline \multicolumn{5}{|c|}{ Hepatico-oxalidosum forest type, fertile dry soil } \\
\hline \multicolumn{3}{|c|}{ No site preparation } & $395 \pm 15$ & $90 \pm 8$ \\
\hline \multicolumn{3}{|c|}{ Furrow depth $10 \mathrm{~cm}$, width $70 \mathrm{~cm}$} & $47 \pm 4 * *$ & $52 \pm 4 * *$ \\
\hline \multirow{7}{*}{ Tilt ploughing: } & \multirow[t]{3}{*}{ berm height } & $10 \mathrm{~cm}$, & $230 \pm 12 *$ & $70 \pm 5^{*}$ \\
\hline & & $20 \mathrm{~cm}$, & $142 \pm 11 * *$ & $64 \pm 3 * *$ \\
\hline & & $30 \mathrm{~cm}$ & $115 \pm 10^{* *}$ & $49 \pm 7 * *$ \\
\hline & \multirow[t]{4}{*}{ berm width } & $40 \mathrm{~cm}$ & $192 \pm 13 * *$ & $61 \pm 2 * *$ \\
\hline & & $60 \mathrm{~cm}$ & $169 \pm 12 * *$ & $63 \pm 3^{* *}$ \\
\hline & & $80 \mathrm{~cm}$ & $115 \pm 10^{* *}$ & $55 \pm 4 * *$ \\
\hline & & $100 \mathrm{~cm}$ & $110 \pm 9^{* *}$ & $51 \pm 8^{* *}$ \\
\hline \multirow{5}{*}{ Strips ploughing: } & \multicolumn{2}{|c|}{ ploughing depth $10 \mathrm{~cm}$, } & $84 \pm 8^{* *}$ & $52 \pm 3 * *$ \\
\hline & \multirow{2}{*}{\multicolumn{2}{|c|}{$\begin{array}{l}20 \mathrm{~cm} \\
30 \mathrm{~cm}\end{array}$}} & $75 \pm 8 * *$ & $54 \pm 4 * *$ \\
\hline & & & $49 \pm 6^{* *}$ & $40 \pm 6^{* *}$ \\
\hline & \multicolumn{2}{|c|}{ ploughing width $60 \mathrm{~cm}$, } & $78 \pm 7 * *$ & $44 \pm 2 * *$ \\
\hline & \multicolumn{2}{|c|}{$100 \mathrm{~cm}$} & $45 \pm 3 * *$ & $42 \pm 7 * *$ \\
\hline \multicolumn{3}{|c|}{ Inverted humus mound (height $20 \mathrm{~cm}$, width $50 \mathrm{~cm}$ ) } & $152 \pm 11 * *$ & $61 \pm 5^{* *}$ \\
\hline \multicolumn{3}{|c|}{ Inverted humus belt (depth $20 \mathrm{~cm}$, width $100 \mathrm{~cm}$ ) } & $118 \pm 9^{* *}$ & $63 \pm 6^{* *}$ \\
\hline \multicolumn{5}{|c|}{ Oxalido-nemorosum forest type, relatively fertile fresh soil } \\
\hline \multicolumn{3}{|l|}{ No site preparation } & $306 \pm 13$ & $70 \pm 3$ \\
\hline \multirow{3}{*}{ Tilt ploughing: } & \multirow{3}{*}{\multicolumn{2}{|c|}{$\begin{aligned} \text { berm height } & 20 \mathrm{~cm}, \\
& 30 \mathrm{~cm}, \\
& 40 \mathrm{~cm}\end{aligned}$}} & $59 \pm 5 * *$ & $42 \pm 6^{* *}$ \\
\hline & & & $65 \pm 5 * *$ & $51 \pm 9 * *$ \\
\hline & & & $68 \pm 7 * *$ & $51 \pm 7 * *$ \\
\hline \multirow{2}{*}{ No site preparation: } & \multirow{2}{*}{\multicolumn{2}{|c|}{$\begin{array}{l}\text { after } 1 \text { year, } \\
\text { after } 3 \text { year }\end{array}$}} & $312 \pm 13 \mathrm{~ns}$ & $34 \pm 6^{* *}$ \\
\hline & & & $318 \pm 15 \mathrm{~ns}$ & $63 \pm 9 \mathrm{~ns}$ \\
\hline \multirow{2}{*}{$\begin{array}{l}\text { Soil piles } \\
(60 \times 80 \times 30 \mathrm{~cm}) \text { : }\end{array}$} & \multirow{2}{*}{\multicolumn{2}{|c|}{$\begin{array}{l}\text { after } 1 \text { year, } \\
\text { after } 3 \text { year }\end{array}$}} & $85 \pm 6^{* *}$ & $65 \pm 5 \mathrm{~ns}$ \\
\hline & & & $221 \pm 11 *$ & $78 \pm 7 \mathrm{~ns}$ \\
\hline \multicolumn{5}{|c|}{ Aegopodiosum forest type, fertile fresh soil } \\
\hline & $186 \pm 10$ & $35 \pm 7$ \\
\hline \multirow[t]{6}{*}{ Tilt ploughing: } & \multicolumn{2}{|c|}{ berm height $20 \mathrm{~cm}$, } & $110 \pm 8^{* *}$ & $22 \pm 6^{* *}$ \\
\hline & (n) & $30 \mathrm{~cm}$ & $83 \pm 6^{* *}$ & $21 \pm 4 * *$ \\
\hline & & $40 \mathrm{~cm}$ & $50 \pm 3 * *$ & $22 \pm 3 * *$ \\
\hline & \multirow{3}{*}{\multicolumn{2}{|c|}{$\begin{array}{r}\text { berm width } 60 \mathrm{~cm}, \\
80 \mathrm{~cm}, \\
100 \mathrm{~cm}\end{array}$}} & $102 \pm 8^{* *}$ & $23 \pm 5^{* *}$ \\
\hline & & & $82 \pm 6^{* *}$ & $22 \pm 4 * *$ \\
\hline & & & $62 \pm 5 * *$ & \\
\hline
\end{tabular}

*,** - significant at the $P \leq 0.05$ and $P \leq 0.01$ probability level, respectively; ns - not significant

Achillea millefolium L., Helichrysum arenarium (L.) Moench, on relatively fertile and fertile dry soils Taraxacum officinale F.H.Wigg., Rumex crispus L. and $R$. acetosella L., Achillea millefolium L., Trifolium repens L., Medicago falcata L., while on fertile fresh soils - Ranunculus auricomus L., T. officinale, Rumex acetosella, A. millefolium and other weed species.

In prepared soil, the number of Gramineae weeds decreased, while Chenopodium album L. and C. glaucum L., Tripleurospermum perforatum (Merat.) M.Lainz, Sonchus oleraceus L., Raphanus raphanistrum L. most often sprouted from seeds. Sometimes overgrowth is formed by Senecio vulgaris L., Artemisia vulgaris L. and A. campestris L., as well as other weeds, typical of the abandoned farmlands.

Adverse effect of weed vegetation on plantations depended not only on their mass, species composition, but also on their height. The height of weeds depended on the method of soil preparation, soil fertility and humidity, weather conditions in the spring and summer. In dry springs and summers the height of weeds was less than in wet years. Their height was greater on temporarily overmoistured than on soils of normal humidity. On soils of the same fertility and humidity, the greatest height of weeds was on completely ploughed soil and on mounds of inverted humus, less - on ploughed berms or piles, while the least on furrows. Despite this, towering weeds, which grow nearby $50-70 \mathrm{~cm}$ deep soil furrows, bent on the side of the furrow and shaded even $30-40 \mathrm{~cm}$ tall seedlings (Table 3). Preparing soil in $100 \mathrm{~cm}$ wide furrows, only individual trees were strongly shaded. Depending on soil preparation method, in the first year of plantation growth, the most shaded were seedlings planted on unprepared soil (3.1 points), while the least shaded were on $100 \mathrm{~cm}$ wide furrows ( 0.8 point) and piles. 
A

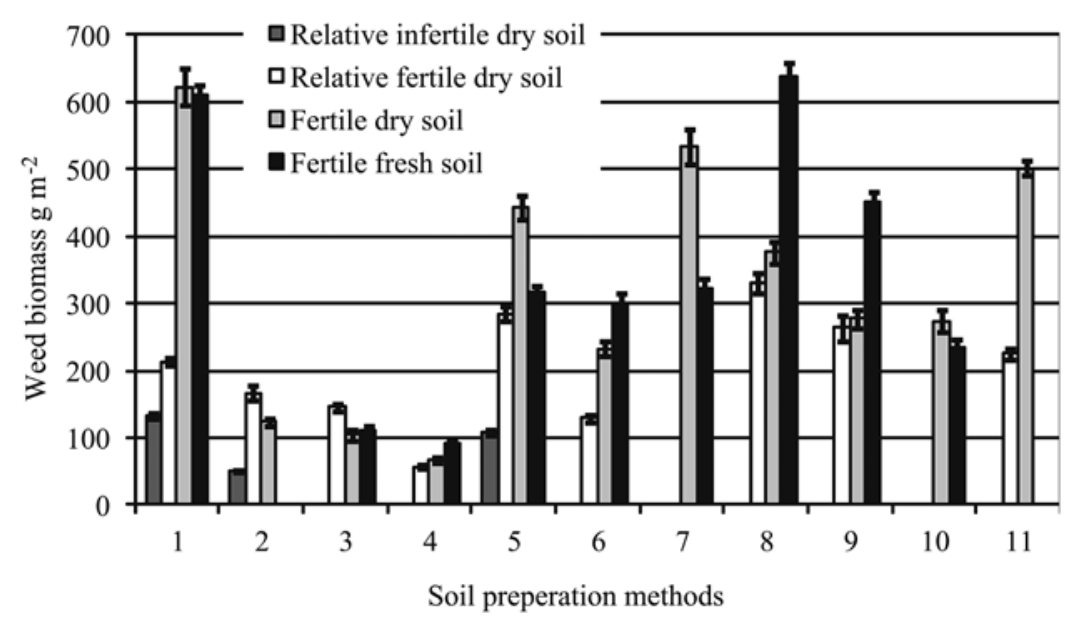

B

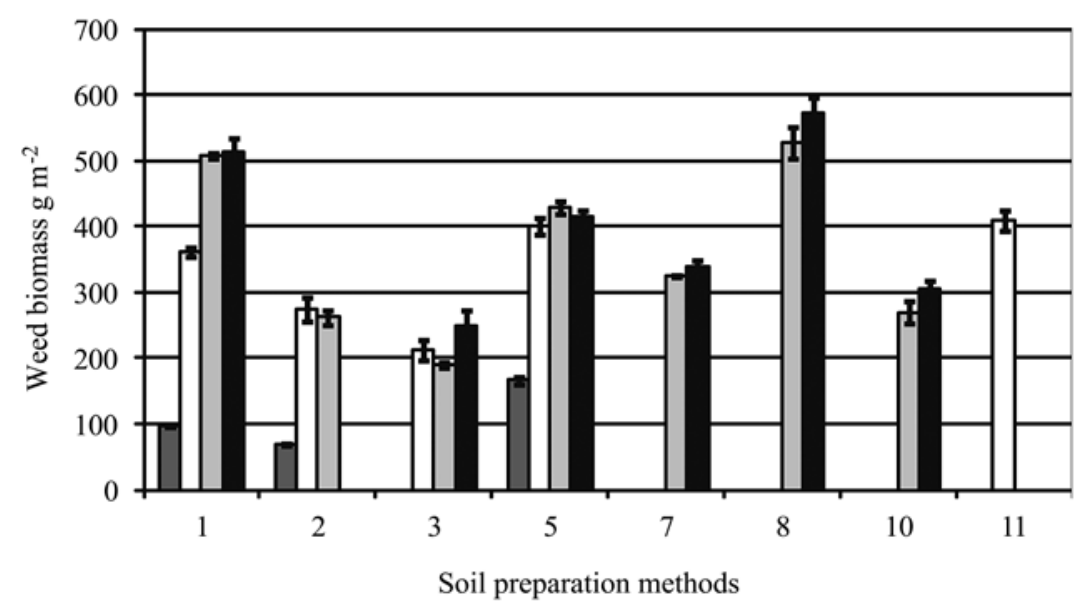

Notes. 1 - no site preparation, 2 - furrow (depth 8-10 cm), 3 - furrow (depth $15 \mathrm{~cm}), 4$ - Roundup Bio $\left(41\right.$ ha $\left.^{-1}\right)+$ furrow (depth $15 \mathrm{~cm}), 5$ - complete site ploughing (depth $22-27 \mathrm{~cm}), 6$ - Roundup Bio $\left(41 \mathrm{ha}^{-1}\right)+$ complete site ploughing (depth $\left.22-27 \mathrm{~cm}\right)$, 7 - tilt ploughing (height $25 \mathrm{~cm}$, width $75 \mathrm{~cm}), 8$ - inverted humus mound (height $20 \mathrm{~cm}$, width $50 \mathrm{~cm}), 9$ - Roundup Bio $\left(41 \mathrm{ha}^{-1}\right)$ + inverted humus mound (height $20 \mathrm{~cm}$, width $50 \mathrm{~cm}), 10$ - soil piles $(60 \times 80 \times 30 \mathrm{~cm}), 11$ - Roundup Bio $\left(41 \mathrm{ha}^{-1}\right)$. Vertical bars represent \pm standard error (SE) of the mean.

Figure. The above-ground biomass of weed vegetation depending on soil preparation methods in the first (A) and second (B) year of forest plantations

Table 3. Shading class and mean time consumption for tending of 100 trees depending on soil preparation methods on relatively fertile and fertile fresh soils

\begin{tabular}{lcc}
\hline \multicolumn{1}{c}{ Soil preparation methods } & $\begin{array}{c}\text { Shading class } \\
(\text { mean } \pm \text { standard error of the mean) }\end{array}$ & $\begin{array}{c}\text { Time consumption for tending of } 100 \text { trees } \\
\text { (mean } \pm \text { standard error of the mean) }\end{array}$ \\
\hline No site preparation (control) & $3.1 \pm 0.3$ & $1 \mathrm{~h} 2^{\prime \prime} \pm 7^{\prime \prime}$ \\
Complete site ploughing & $2.6 \pm 0.2^{*}$ & $58^{\prime \prime} \pm 5^{\prime \prime} \mathrm{ns}$ \\
Tilt ploughing & $2.1 \pm 0.4^{* *}$ & $40^{\prime \prime} \pm 6^{\prime \prime *}$ \\
Soil mound & $0.7 \pm 0.1^{* *}$ & $28^{\prime \prime} \pm 6^{\prime \prime * *}$ \\
Inverted humus mound & $2.6 \pm 0.3^{*}$ & $59^{\prime \prime} \pm 4^{\prime \prime} \mathrm{ns}$ \\
Furrow (depth $8-10 \mathrm{~cm}$, width $50 \mathrm{~cm})$ & $2.0 \pm 0.5^{* *}$ & $38^{\prime \prime} \pm 3^{\prime \prime * *}$ \\
Furrow (depth $15 \mathrm{~cm}$, width $100 \mathrm{~cm})$ & $0.8 \pm 0.2^{* *}$ & $30^{\prime \prime} \pm 4^{\prime * * *}$ \\
Furrow (depth $15 \mathrm{~cm}$, width $70 \mathrm{~cm}$ ) & $1.2 \pm 0.4^{* *}$ & $31^{\prime \prime} \pm 5^{\prime \prime * *}$ \\
\hline
\end{tabular}

*, ** - significant at the $P \leq 0.05$ and $P \leq 0.01$ probability level, respectively; ns - not significant 
Soil preparation method influences also the volume and time consumption for tending. The greatest time consumption is required for the tending of unprepared, prepared in mounds or completely ploughed soil - 58-62 minutes per 100 trees for onetime tending, the least - soil prepared in piles or $100 \mathrm{~cm}$ wide furrows (28-30 minutes per 100 trees).

\section{Discussion}

The height of ground vegetation depends on soil preparation method, soil fertility and humidity, on the species of grasses, spring and summer weather conditions. All soil preparation methods reduced the biomass of weeds on fresh cutovers in the first year of plantation growth, as compared to unprepared soil. The effect of soil preparation was increasing with increasing soil preparation depth and width. In the third year, the biomass of weeds in the soil prepared in piles $(60 \times 80$ $\times 30 \mathrm{~cm}$ ) was significantly higher in comparison with unprepared soil. The obtained data essentially agree with the results provided by other authors. The mass of weeds in the soil prepared by any method was lower than in the control. Having prepared soil in advance, tending of the plantation in the first year was unnecessary (Вячкилев и др., 1980). Having prepared the soil in relatively thin tilts (15-25 cm thickness), weeds fully recover already in the second year, while having prepared in relatively thick tilts $(20-50 \mathrm{~cm})$, tending of the plantation is necessary only in the third year (Маслаков, Маркова, 1978). Depending on the method of soil preparation, the following tending of the plantation is required: in unprepared soil - in the first year and later, on prepared soil, depending on the abundance of weeds, in the second and the third year (Лиепа, 1982). In the second and the third year, weeds on ploughed tilts develop 2-4 times more slowly than on unprepared soil (Ковалев, Ковалев, 1986). Mechanical soil preparation, as compared to unprepared soil, affects the growth of weeds for a very short time. On the soil prepared with ploughs producing $20-50 \mathrm{~cm}$ thick berms, weeds start sprouting in the second year.

Soil preparation methods on former farmland often had less influence on the biomass of weeds than on forest soils. The lowest mass of weeds was found on furrows, while complete soil ploughing, preparation in mounds of inverted humus or weed-killing with Roundup Bio reduced the mass of weeds less distinctly, or even increased it. Soil preparation, especially if weeds are killed with herbicides prior to mechanical soil preparation, modifies species composition of weeds, decreases the amount of graminoids (Gramineae) and other perennial grasses, meanwhile, annual weeds start sprouting. Following soil preparation on former farmland, ground vegetation spreads already in the first year. Even complete soil ploughing (tillage and harrowing before planting), leaving the soil weed-free, fails to ensure good development of seedlings. The seeds of annual plants sprout and quickly occupy the whole area (Ferm et al., 1994). Preparation of the soil before establishing a plantation has a positive effect on the growth of tree- plants, but this effect is of short duration due to fast spreading of weeds (Vares et al., 2001).

Annual weeds most frequently are herbaceous forbs. Herbaceous forbs can be less competitive than graminoids for soil resources (Coll et al., 2003); however, forbs compete the most efficiently for light (Frochot et al., 2002). The root growth of forbs is slower than that of grass species, especially during increasing soil drought. Thus, such a change of herbaceous vegetation after soil preparation in the first year of plantation growth may increase survival of trees. All in all, the growth of seedlings was higher with forbs than with grasses (Balandier et al., 2006).

The above-ground mass of weeds in the soils of similar fertility on former farmland was higher than in fresh clear-cuts and, depending on soil fertility, comprised on an average 134-612 $\mathrm{g} \mathrm{m}^{-2}$. The development of ground vegetation after soil preparation in the field is faster and more vigorous than on the forest soil (Hytönen, Jylhä, 2005). The biomass of weeds may be extremely high, especially that of the below ground portion. In Finland, in 51 fields that had not been cultivated for between one and six years, the dry biomass of weeds comprised $274 \mathrm{~g} \mathrm{~m}^{-2}$ and below ground - $1054 \mathrm{~g} \mathrm{~m}^{-2}$ (Hytönen, Jylhä, 2005). Despite the differences in soil - climatic conditions between Finland and Lithuania, it is possible to state that our results are very similar to those obtained in Finland.

\section{Conclusions}

1. Preparation of soil in furrows, tilts or piles in fresh forest clear-cut areas of mineral soils differing in fertility, reduced the above-ground biomass of ground vegetation by up to 4-9 times in comparison with unprepared soil.

2. Soil preparation on former farmland had a distinct, but significantly less influence than on forest soils. In the first-year-old forest plantations on former farmland, the lowest biomass of weeds was found on furrows. Complete ploughing to the depth of 22-27 cm, preparation in mounds of inverted humus or weed-killing with Roundup Bio reduced the mass of weeds by up to two times. In the one-year-old forest plantations, the differences in the above-ground biomass of weeds among different soil preparation treatments decreased.

3. Soil preparation method determined the shading class of seedlings and the intensity of plantation tending. The least shaded were seedlings planted on wide $(100 \mathrm{~cm})$ furrows and $30 \mathrm{~cm}$ high piles, the most shaded were seedlings planted on unprepared, completely ploughed soil or on inverted humus mounds. Tending intensity of 100 trees was directly dependant on the shading class.

Received 02122013 Accepted 31072014 


\section{References}

Balandier P., Collet C., Miller J. H., Reynolds P. E., ZedakerS. M. 2006. Designing forest vegetation management strategies based on the mechanisms and dynamics of crop tree competition by neighbouring vegetation. Forestry, 79: 3-27

http://dx.doi.org/10.1093/forestry/cpi056

Buivydaitè V., Vaičys M., Juodis J., Motuzas A. 2001. Classification of the soils of Lithuania. Vilnius (in Lithuanian)

Coll L. I., Balandier P., Picon-Cochard C., Prevesto B., Curt T. 2003. Competition for water between beech seedlings and surrounding vegetation in diferent light and vegetation composition conditions. Annals of Forest Sciences, 60: 593-600 http://dx.doi.org/10.1051/forest:2003051

Ferm A., Hytönen J., Lilja S., Jylhä P. 1994. Effect of weed control on the early growth of Betula pendula seedlings established on an agricultural field. Scandinavian Journal of Forest Research, 9: 347-359 http://dx.doi.org/10.1080/02827589409382851

Frochot H., Armand G., Gama A., Nouveau M., Wchrlen, L. 2002. La gestion de la vegetation accompagnatrice: étar et persoective. Revue forestière française, 54 (6): 505-520 (in French)

Gemmel P., Nilsson U., Welander T. 1996. Development of oak and beech seedlings planted under varying shelterwood densities and with different site preparation methods in southern Sweden. New Forests, 12: 141-161

Hytönen J., Ekola E. 1993. Soil nutrient regime and tree nutrition on afforested fields in central Ostrobothnia, western Finland. Folia Forestalia, 822, 32 p.

Hytönen J., Wall A. 1997. Nutrients amounts of afforested peat fields and neighbouring peatland forests. Suo, 48 (2): 33 42 (in Finnish)

Hytönen J., Jylhä P. 2005. Effects of competing vegetation and post-planting weed control on the mortality, growth and vole damages to Betula pendula planted on former agricultural land. Silva Fennica, 39 (3): 365-380 http://dx.doi.org/10.14214/sf.374

Karazija S. 1988. Lietuvos mišku tipai [Lithuanian forest types], p. 67-73 (in Lithuanian)

Kiirikki M. 1993. Seed bank and vegetation succession in abandoned fields in Karkali Nature Reserve, southern Finland. Annales Botanici Fennici, 30 (2): 139-152

Malinauskas A., Urbaitis G. 2002. Species composition, growth and conditions of trees in forest plantations and naturaly regenerated forest on abandoned agricultural lands. Miškininkystè, 2 (52): 71-80 (in Lithuanian)

Malinauskas A., Urbaitis G. 2010. Soil preparation for forest plantationsin former farmland Haplic Arenosols with and withhout plough-pan. Baltic Forestry, 16 (2): 247-254

Miller J. H., Zutter B. R., Newbold R. A., Edwards M. B., Zedaker S. M. 2003. Stand dynamics and plant associates of loblolly pine plantations to mid rotation after early intensive vegetation management - a south-eastern United States regional study. Journal of Applied Forestry, 27: 221-236

Pawers R., Reynolds P. 1999. Ten-year responses of ponderosa pine plantations to repeated vegetation and nutrient control along an environmental gradient. Canadian Journal of Forest Research, 29: 1027-1038

http://dx.doi.org/10.1139/x99-104
Reynolds P., Currt R. Bell F. 2002. Effects of controlled weed densities, soil types, weed species and duration of weed establishment on seedling microclimate and seedling growth. $4^{\text {th }}$ international conference on forest vegetation management: Populus summaries / compiled by Frochot $\mathrm{H}$. et al. Institut National de la Recherche Agonomique, p. $258-260$

Rose R., Ketchum J. S. 2003. Interaction of initial seedling diameter, fertilization and weed control on Douglas-fir growth over the first four years after planting. Annals of Forest Science, 60: 1-11 http://dx.doi.org/10.1051/forest:2003055

Rossi S., Varmola M., Hyppönen M. 1993. Success of afforestation of fields in Finnish Lapland. Folia Forestalia, $807,23 \mathrm{p}$.

Smirh D., Larson B., Kelry M., Ashton P. 1997. The practice of silviculture: applied forest ecology $\left(9^{\text {th }}\right.$ ed. $)$. New York, USA

Thompson D. G., Pitt D. G. 2003. A review of Canadian forest vegetation management research and practice. Annals of Forest Science, 60: 559-572 http://dx.doi.org/10.1051/forest:2003060

Vares A., Jõgiste K., Kull E. 2001. Early growth of some deciduous tree species on abandoned agricultural lands in Estonia. Baltic Forestry, 7 (1): 52-58

Вячкилев В. В., Карцев А. Д., Максимов В. Е. 1980. Influence of soil scarification on survival and growth of spruce plantations. Восстановление мелиорированных лесов северо-запада РСФСР, с. 73-77 (in Russian)

Ковалев Л. С., Ковалев М. С. 1986. Dynamics of development and growth of grass vegetation on clear-cut areas. ЮжноСахалинский государственный педагогический институт, 27 c. (in Russian)

Лиепа Ю. Т. 1982. Influence of technology of the establishment of spruce plantation on grass and woody vegetation growth in Oxalidosum site type. Труды Латвийской сельскохозяйственной академии, 194: 21-28 (in Russian)

Маслаков Е. Л., Маркова И. А. 1978. Forest regeneration on clear-cut areas in north-west taiga, 41 c. (in Russian)

Юряленис Ю. В. 1975. Bioecological and biochemical subjects influencing the establishment of forest association on clear-cut areas in south Baltic: автореферат на соискание степени кандидата сельскохозяйственных наук, 27 с. (in Russian) 
ISSN 1392-3196 / e-ISSN 2335-8947

Zemdirbyste-Agriculture, vol. 101, No. 4 (2014), p. 395-402

DOI $10.13080 / \mathrm{z}-\mathrm{a} .2014 .101 .050$

\title{
Dirvos paruošimo įtaka žolinių augalų vystymuisi miško želdiniuose žemès ūkiui naudotuose plotuose ir kirtavietėse
}

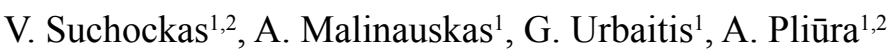 \\ ${ }^{1}$ Lietuvos agrarinių ir miškų mokslų centro Miškų institutas \\ ${ }^{2}$ Aleksandro Stulginskio universitetas
}

\section{Santrauka}

Tirta dirvos paruošimo ịtaka žolinių augalų ir puskrūmių vystymuisi veisiant miško želdinius. Nustatyta, kad žemės ūkiui naudotose žemèse pirmųjų metų želdiniuose žolès mažiausia masė užaugo išartose vagose. Dirvos ištisinis suarimas 22-27 cm gyliu, paruošimas humusiniais volais ar piktžolių sunaikinimas herbicidu Roundup Bio jų masę gali sumažinti iki dviejų kartų. Piktžolių masę visada mažino dirvos paruošimas riekėmis ir kauburèliais. Antraisiais želdinių augimo metais piktžolių masès skirtumai tarp įvairių dirvos variantų sumažejo.

Šviežiose derlingų mineralinių dirvožemių kirtavietėse žolinių augalų biomasę mažina bet kuris mechaninis dirvos paruošimo būdas. Didèjant žemès dirbimo gyliui (iki $40 \mathrm{~cm}$ ) ir apdirbamos juostos pločiui (iki $100 \mathrm{~cm}$ ), paruoštoje dirvoje žolinių augalų masė mažèjo. Mažiausia (4-9 kartus mažesnė, lyginant su neruošta dirva) žolinių augalų biomasè buvo vagomis, storomis riekèmis arba dideliais kauburèliais paruoštoje dirvoje. Dirvos paruošimo būdas (mechaninis ir cheminis) turejjo ịtakos ir žolinių augalų aukščiui. Jis taip pat priklausė nuo dirvos derlingumo ir drègnumo, žolių rūšių, pavasario ir vasaros orų sąlygų (kritulių kiekio vegetacijos sezono metu ir oro temperatūros). Dirvos paruošimo būdas taip pat sąlygojo sodinukų užpavėsinimo laipsnį ir želdinių priežiūros apimtis. Mažiausiai stelbti plačiose (100 cm pločio) vagose ir ị $30 \mathrm{~cm}$ aukščio kauburèlius pasodinti medeliai, daugiausia - neruoštoje, ištisai suartoje arba paruoštoje volais dirvoje.

Reikšminiai žodžiai: dirvos paruošimas, dirvos riekè, miško želdiniai, vaga, žolinės augalijos išsivystymas. 